\title{
Evaluasi Ketersediaan Gate Di Terminal 3 Ultimate Bandar Udara Internasional Soekarno- Hatta
}

\author{
Andree Noviar Pradana, Ervina Ahyudanari, dan Istiar \\ Jurusan Teknik Sipil, Fakultas Teknik Sipil dan Perencanaan, Institut Teknologi Sepuluh Nopember (ITS) \\ Jl. Arief Rahman Hakim, Surabaya 60111 \\ e-mail: ervina@ce.its.ac.id; istiar@ce.its.ac.id
}

\begin{abstract}
Abstrak - Gate sebagai akses yang digunakan untuk proses perpindahan penumpang dari terminal menuju ke sisi udara bandara. Dan sebaiknya untuk itu, pengaturan gate sangat berpengaruh dalam mengoptimalkan waktu pemakaian mulai dari pesawat mendarat hingga keberangkatan selanjutnya. Dalam evaluasi ketersediaanya gate terkadang hanya diperuntukkan untuk maskapai tertentu. Hal ini mempengaruhi jumlah gate yang tersedia. Adapun keterlambatan penerbangan yang terjadi juga dapat disebabkan oleh pengaturan gate yang kurang optimal, sehingga pesawat harus mengantri untuk lepas landas ataupun parkir di apron. Dalam mengevaluasi ketersediaan gate, maka dilakukan pengumpulan data aktivitas pesawat selama parkir di apron. Data yang diperoleh adalah data waktu block on dan block off, data penggunaan parking stand, dan jadwal penerbangan pesawat tiap maskapai. Data-data tersebut kemudian diplot sesuai jadwal penerbangan. Dari hasil plotting dapat diketahui gate-gate yang masih memungkinkan untuk digunakan. Dari hasil evaluasi yang telah dilakukan didapatkan hasil bahwa dari 167 turnaround flight hanya 10 penerbangan yang dapat melakukan pelayanan ground handling secara on time. Dan dari hasil peramalan didapatkan di tahun 2025 gate sudah tidak dapat melayani secara optimal. Sehingga dapat disimpulkan bahwa jumlah gate belum memenuhi kebutuhan pergerakan pesawat yang beroperasi terutama pada peak hour.
\end{abstract}

Kata Kunci-Apron, Evaluasi Ketersediaan Gate, Pergerakan Pesawat, Parking Stand, Gate.

\section{PENDAHULUAN}

$\mathrm{B}$ ANDAR udara Internasional Soekarno-Hatta merupakan bandara terbesar di Indonesia, bandar udara yang dikelola oleh PT. Angkasa Pura II ini terletak di dekat Cengkareng, Jakarta barat namun secara geografis terletak di Kecamatan Benda, Kota Tangerang dengan luas 1740 Ha. Berdasarkan Keputusan Menteri Perhubungan No. 11 tahun 2010 tentang Tatanan Kebandarudaraan Nasional [1], Bandara Internasional Soekarno-Hatta dikategorikan sebagai bandara pengumpul dengan skala pelayanan primer dengan jumah lebih besar atau sama dengan 5.000.000 (lima juta) orang pertahun, dan menjadikan bandara ini sebagai bandara tersibuk di Indonesia dengan rata-rata pertumbuhan penumpang sebesar 19,2\% [2]. Dalam rangka mengatasi pertumbuhan tersebut maka dikembangkan fasilitas Bandara Soekarno-Hata untuk menampung penumpang sebesar 62 juta penumpang per tahun, salah satu solusinya dengan dibangunnya Terminal 3 Ultimate yang direncanakan akan menampung kapasitas pergerakan 25 juta penumpang. Terminal penumpang merupakan salah satu bagian terpenting dari bandar udara yang memiliki berfungsi sebagai tempat berlangsungnya segala kegiatan penumpang dari mulai keberangkatan hingga kedatangan. Komponen terminal dalam melayani penumpang terbagi 3 (tiga bagian fasilitas yang meliputi keberangkatan (departure), kedatangan (arrival), serta peralatan fasilitas penunjang bandar udara seperti curbside, check-in area, baggage claim, ruang tunggu serta gate penumpang, dan adapun komponen fasilitas dalam Terminal 3 tersebut yang akan saya evaluasi adalah Gate penumpang.

Penggunaan serta ketersediaan gate harus mencukupi dalam pelayanan penumpang, dengan melihat adanya pergerakan penumpang di Bandar Udara Soekarno-Hatta gate yang ada haruslah mencukupi jumlahnya serta kenyamanannya, penggunaan gate itu sendiri dipengaruhi oleh lama waktu pemakaian dan waktu pengosongan gate. Lamanya waktu pemakaian gate ini berbeda-beda tergantung dari pelayanan boarding oleh pihak airlines dan penumpang yang akan melakukan penerbangan. Lama waktu pemakaian gate itu sendiri adalah waktu yang diperlukan untuk proses pergerakan penumpang dari ruang tunggu menuju pesawat, perjalanan tersebut dapat dilakukan dengan cara berjalan kaki maupun menggunakan bis yang disediakan oleh pihak bandara Soekarno-Hatta. Oleh karena itu tata letak posisi parkir pesawat di apron sangat menentukan fasilitas penumpang saat menuju bis. penggunaan gate berhubungan terhadap kesiapan pesawat di apron karena ketika melakukan kegiatan akan mempengaruhi boarding time. Boarding time itu sendiri adalah waktu dibukanya gate penumpang [3] dan penumpang dipersilahkan masuk. Adapun kegiatan itu mulai dari penumpang turun, pembersihan kabin, pengecekan mesin, pengisian bahan bakar serta mengeluarkan bagasi. Setiap pesawat memiliki jenis dan karakteristik yang berbeda-beda, oleh karena itu semakin besar pesawat dan banyak penumpang maka semakin lama juga waktu pemakaian gate tersebut [4].

Terminal 3 Ultimate adalah terminal yang akan melayani penerbangan internasional di bandara Soekarno-Hatta yang bertujuan untuk meningkatkan kinerja terminal penerbangan internasional, dan diharapkan dengan adanya terminal 3 ultimate ini akan mengatasi masalah overload atau over kapasitas yang terjadi di terminal 2 saat ini. Jumlah maskapai yang akan dilayani oleh terminal 3 ultimate sebanyak 54 maskapai terdiri dari maskapai Garuda dan maskapai-maskapai yang tergabung dalam Sky Team sedangkan sisanya untuk maskapai lain yang memiliki rute internasional. Adapun gate yang direncanakan di terminal 3 ultimate berjumlah total 14 gate [5].

Adanya kondisi yang berhubungan diatas terkait dengan peningkatan pergerakan penumpang dan kepadatan jadwal penerbangan serta kenyamanan gate maka perlu diadakan evaluasi terhadap ketersediaan gate, jadwal penerbangan pesawat, jenis dan kapasitas pesawat, kapasitas tempat duduk, ruang untuk berdiri yang ada di sektar gate, serta kesiapan pesawat di apron yang berhubungan dengan waktu dimulainya boarding. Dari permasalahan tersebut, yang sekiranya penting adalah mengetahui frekuensi lama waktu pemakaian gate dan pengosongan gate, prosentase lama waktu pengosongan dan pemakaian gate, perhitungan /penggambaran kegiatan pesawat di apron. Hasil evaluasi tersebut diharapkan dapat digunakan sebagai bahan rujukan dalam merencanakan pemakaian jumlah gate yang diperlukan.

Seperti yang sudah dijelaskan di atas, evaluasi ketersediaan gate terminal Bandara Internasional Soekarno-Hatta memiliki beberapa permasalahan yang harus diatasi. Adapun rumusan masalah tersebut adalah:

1. Bagaimana perkiraan karakteristik pergerakan pesawat yang dilayani Terminal 3 Ultimate?

2. Bagaimana kecukupan gate yang tersedia terhadap rencana pergerakan penerbangan internasional di terminal 3 ultimate pada tahun 2025 ? 
3. Bagaimana kinerja terminal 3 ultimate dengan gate-gate yang tersedia di terminal tersebut dan berapa penerbangan yang dapat dilayani tiap-tiap gate

Manfaat yang diperoleh dalam evaluasi gate terminal ini diharapkan dapat mengetahui ketersediaan jumlah serta pelayanan gate yang sesuai dengan kondisi Bandara Internasonal Soekarno-Hatta, selain itu manfaat dari Tugas Akhir ini adalah mendapat pemahaman tentang fasilitas terminal di bandara.

\section{METODOLOGI}

Pada bab metodologi, disajikan tahapan penyelesaian masalah yang ada dalam studi ini. Pada Gambar 1 ditunjukkan gambar bagan alir metodologi secara lengkap.

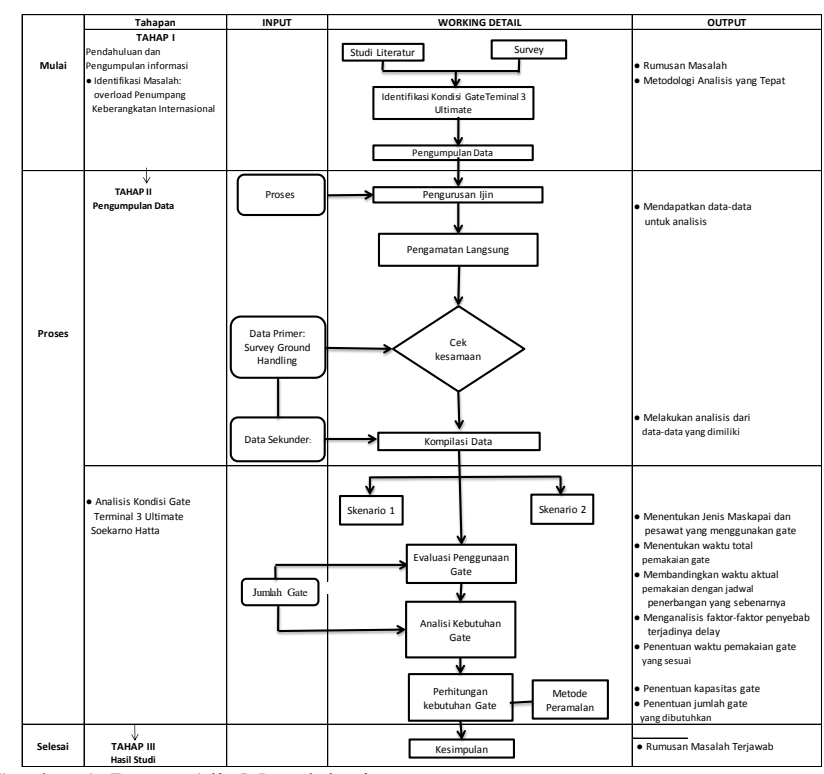

Gambar 1. Bagan Alir Metodologi

\section{HASIL DAN PEMBAHASAN}

A. Analisis Karakteristik Pesawat yang Menggunakan Gate

Dalam mengevaluasi ketersediaan gate pada Terminal 3 Ultimate Bandar Udara Soekarno-Hatta, siperlukan distribusi penggunaan gate oleh airline, yang dapat dilihat pada tabel 1 untuk menentukan gate mana saja yang pemakaiannya dipisah dan dicampur, sehingga mempermudah dalam mengatur jadwal penerbangan yang sesuai [6].

Dari tabel 1 tersebut dapat diketahui bahwa dari 14 gate yang ada, 7 diantaranya merupakan shared gate, yaitu digunakan oleh beberapa maskapai sekaligus, sedangkan 7 gate sisanya adalah untuk maskapai Garuda Indonesia.

Waktu Pemakaian gate kegiatan pesawat (aircraft turnaround) dimulai saat pesawat melakukan block on, block off dan garabarata dilepas [7]. Seluruh kegiatan ini secara normal memakan waktu 40 hingga 60 menit. Berdasarkan data penerbangan yang ada, berikut rata-rata variasi waktu pemakaian yang terjadi dapat dilihat pada Gambar 2.

Tabel 1.

Distribusi Penggunaan Gate oleh Airline

\begin{tabular}{|c|c|c|c|c|c|c|c|c|}
\hline Gate & \multicolumn{8}{|c|}{ Airline } \\
\hline 4 & $\begin{array}{c}\text { Garuda } \\
\text { Indonesia }\end{array}$ & $\begin{array}{c}\text { Indonesia } \\
\text { Airasia }\end{array}$ & Emirates & $\begin{array}{l}\text { Qatar } \\
\text { Airways }\end{array}$ & $\begin{array}{l}\text { Jetstar } \\
\text { Asia }\end{array}$ & $\begin{array}{l}\text { Vietnam } \\
\text { Airllines }\end{array}$ & $\begin{array}{l}\text { Turkish } \\
\text { Airlines }\end{array}$ & \\
\hline 5 & $\begin{array}{c}\text { Garuda } \\
\text { Indonesia }\end{array}$ & & & $\begin{array}{l}\text { Qatar } \\
\text { Airways }\end{array}$ & & & & $\begin{array}{l}\text { Indonesia } \\
\text { Airasia X }\end{array}$ \\
\hline 6 & $\begin{array}{l}\text { Garruda } \\
\text { Indonesias }\end{array}$ & & & & $\begin{array}{l}\text { Jetstar } \\
\text { Asia }\end{array}$ & & & \\
\hline 7 & $\begin{array}{c}\text { Garuda } \\
\text { Indonesia }\end{array}$ & $\begin{array}{c}\text { Indonesia } \\
\text { Airasia }\end{array}$ & & & $\begin{array}{l}\text { Thtstar } \\
\text { Assia }\end{array}$ & & & $\begin{array}{l}\text { Indonesia } \\
\text { Airasia X }\end{array}$ \\
\hline 8 & $\begin{array}{l}\text { Garuda } \\
\text { Indonesia }\end{array}$ & $\begin{array}{c}\text { Indonesia } \\
\text { Airasia } \\
\end{array}$ & & & & & & $\begin{array}{l}\text { Indonesia } \\
\text { Airasia X }\end{array}$ \\
\hline 9 & $\begin{array}{c}\text { Garuda } \\
\text { Indonesia }\end{array}$ & 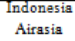 & & & & & & \\
\hline 10 & $\begin{array}{c}\text { Garnda } \\
\text { Indonesia }\end{array}$ & $\begin{array}{c}\text { Indonesia } \\
\text { Airasias } \\
\end{array}$ & Emirates & & & & & $\begin{array}{l}\text { Indonesia } \\
\text { Airasia X } \\
\end{array}$ \\
\hline 11 & $\begin{array}{l}\text { Grandala } \\
\text { Indonesia }\end{array}$ & & & & & & & \\
\hline 12 & $\begin{array}{c}\text { Garnda } \\
\text { Indonesia }\end{array}$ & & & & & & & I \\
\hline
\end{tabular}

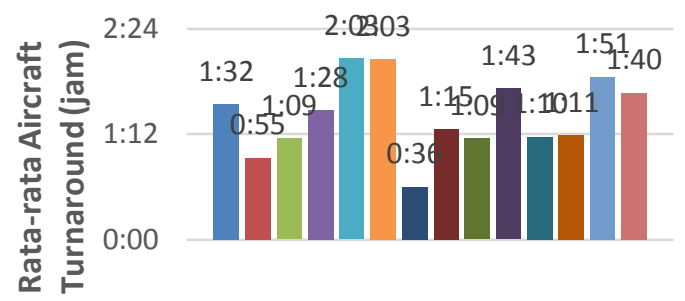

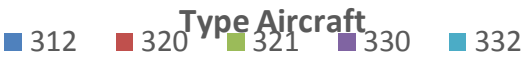

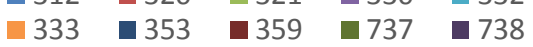

$$
\begin{aligned}
& \square 739 \square 772 \square 773 \square 788
\end{aligned}
$$

Gambar 2. Variasi Okupansi Gate Berdasarkan Tipe Pesawat

\section{B. Analisis Kinerja Gate Assignment}

Dari 14 gate yang ada, tidak seluruhnya digunakan secara terus-menerus selama jam operasional bandara seperti yang tersaji dalam Gambar 3 dapat dilihat bahwa penggunaan gate yang paling banyak terjadi pada gate 11 . Sementara pemakaian gate paling sedikit adalah gate 8 dan gate 17. Dari data tersebut dapat dibuat variasi waktu okupansi per gate seperti Gambar 4.

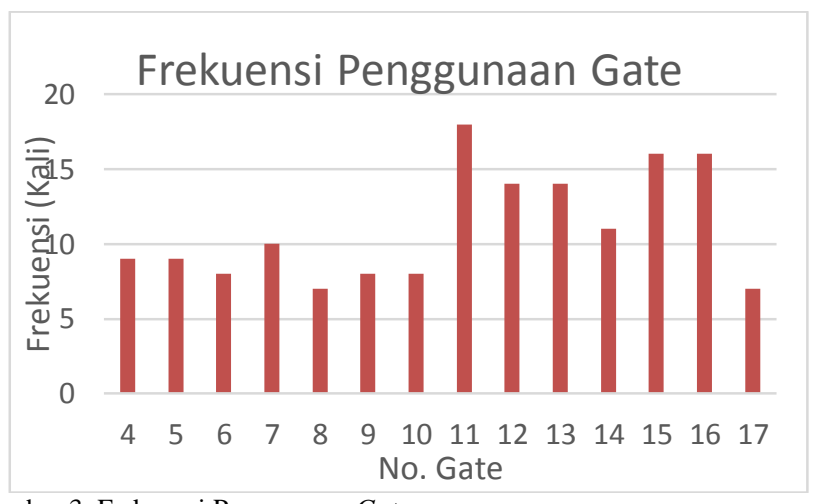

Gambar 3. Frekuensi Penggunaan Gate

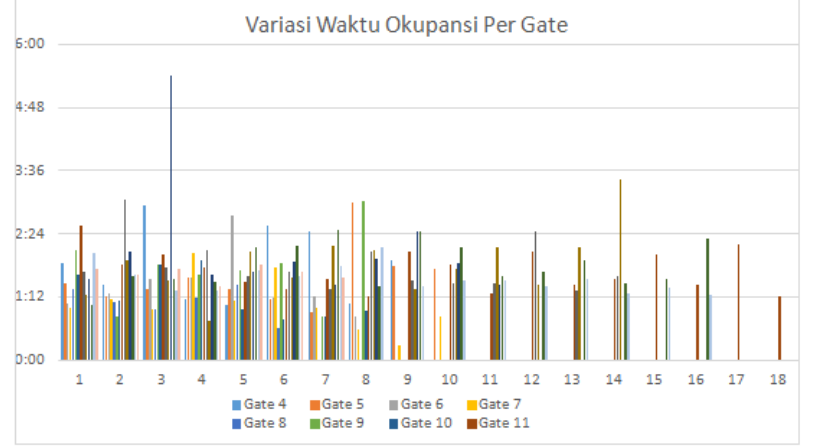

Gambar 4. Variasi Waktu Okupansi Per Gate

Lama waktu kegiatan tersebut dicatat di form waktu kegiatan yang bernama ramp activity checklist [4]. Dari hasil survey, didapat data waktu ramp activity yang dapat dilihat pada Tabel 2.

Tabel 2.

Rekapitulasi Pengamatan Langsung Waktu PemakaianGate

\begin{tabular}{|c|c|c|c|c|}
\hline \multirow{2}{*}{ Operations } & \multirow{2}{*}{$\begin{array}{l}\text { Waktu Estimasi } \\
\text { (menit) }\end{array}$} & \multicolumn{3}{|c|}{ Waktu Aktual (menit) } \\
\hline & & QZ 0257 & GA 0873 & QZ 203 \\
\hline Mematikanmesin & & 1.0 & 0.0 & 0.0 \\
\hline Penumpang turun daripesawat & 4.4 & 5.0 & 6.0 & \\
\hline Mengecek log book & 1.5 & 5.0 & 5.0 & 9.0 \\
\hline Membongkarmuatan & 20.8 & 7.0 & 11.0 & 7.0 \\
\hline Service gallery & 29.1 & 10.0 & 18.0 & 10.0 \\
\hline Cabin service & 16.0 & 10.0 & 18.0 & 10.0 \\
\hline Pengisian bahan bakar & 23.0 & 20.0 & & \\
\hline Pemeriksaankeliling & 9.0 & 5.0 & 7.0 & 5.0 \\
\hline Mengangkut muatan & 19.9 & 21.0 & 13.0 & 10.0 \\
\hline Pengecekanlogbook & 1.4 & 2.0 & & \\
\hline Penumpangnaik ke pesawat & 5.6 & 10.0 & 11.5 & 8.0 \\
\hline Menyalakanmesin & 3.0 & 3.0 & & \\
\hline Melepaskan garbarata & 0.5 & 2.0 & 2.0 & 2.0 \\
\hline $\begin{array}{l}\text { Mengosongkan area untuk } \\
\text { keberangkatan }\end{array}$ & 1.0 & 1.0 & 2.0 & 1.0 \\
\hline Total Gate Occupar & e (menit) & 51.0 & 94.5 & 63.0 \\
\hline
\end{tabular}

Berdasarkan Tabel 2 dapat diketahui lama waktu pemakaian total gate occupancy time untuk penerbangan Air Asia QZ 0257 adalah mulai pukul 11.16 hingga pukul 13.00 atau selama 144 menit. Lama waktu tersebut melebihi estimasi waktu yang seharusnya sekitar 30-40 menit, dapat dilihat ada beberapa kegiatan dilakukan melebihi waktu yang ada. 


\section{Perhitungan Kapasitas Gate}

Kapasitas gate merujuk kepada kemampuan dari sejumlah gate tertentu untuk mengakomodasi proses bongkar muat dalam kondisi permintaan yang terus-menerus. Hal ini adalah inverse dari gate occupancy time rata-rata untuk seluruh pesawat yang dilayani [6].

Untuk menentukan kapasitas gate ini, diperlukan data aircraft class yang menggunakan gate yang tersedia, seperti yang ditunjukkan dalam Tabel 3.

Tabel 3.

Aircraft Class yang Beroperasi di Terminal 3 Bandar Udara Internasional Soekarno-Hatta.

\begin{tabular}{|c|c|c|c|}
\hline No & Tipe & $\begin{array}{c}\text { Kapasitas } \\
\text { (seat) }\end{array}$ & Kategori \\
\hline 1 & CRJ & 50 & B \\
\hline 2 & 312 & 240 & D \\
\hline 3 & 320 & 180 & C \\
\hline 4 & 321 & 220 & C \\
\hline 5 & 330 & 295 & C \\
\hline 6 & 332 & 253 & C \\
\hline 7 & 333 & 295 & C \\
\hline 8 & 353 & 295 & C \\
\hline 9 & 359 & 325 & C \\
\hline 10 & 737 & 189 & C \\
\hline 11 & 738 & 189 & C \\
\hline 12 & 739 & 220 & C \\
\hline 13 & 772 & 440 & C \\
\hline 14 & 773 & 365 & C \\
\hline 15 & 788 & 210 & C \\
\hline 16 & 789 & $250-290$ & C \\
\hline
\end{tabular}

Berdasarkan Tabel 3 dapat diketahui bahwa ada 16 pesawat yang beroperasi di Terminal 3 Bandar Udara Internasional Soekarno-Hatta yang mewakili 2 kategori yang berbeda yaitu kategori B dan C. Dalam menentukan kapasitas gate, dilakukan perhitungan yang berbeda untuk gate yang penggunaannya dicampur dengan gate yang penggunaannya secara eksklusif untuk maskapai tertentu.

\section{Kapasitas Penggunaan Gate yang Dicampur}

Kapasitas gate mengacu pada kemampuan sejumlah tertentu gerbang untuk mengakomodasi pemuatan pesawat dan operasi bongkar muat dalam kondisi permintaan yang terus-menerus [8].

Berdasarkan distribusi penggunaan gate oleh airline diketahiu bahwa dari 14 gate yang tersedia di Terminal 1 Bandara Internasional Soekarno-Hatta

Tabel 4.

Kompetisi Kategori Pesawat yang Beroperasi di Shared Gate Terminal 3 Ultimate

\begin{tabular}{|c|c|c|c|}
\hline No & Tipe & Kategori & $\begin{array}{c}\text { Jumlah } \\
\text { (buah) }\end{array}$ \\
\hline 1 & 312 & C & 2 \\
\hline 2 & 320 & $\mathrm{C}$ & 14 \\
\hline 3 & 321 & $\mathrm{C}$ & 2 \\
\hline 4 & 330 & C & 1 \\
\hline 5 & 332 & $\mathrm{C}$ & 3 \\
\hline 6 & 333 & $\mathrm{C}$ & 5 \\
\hline 7 & 353 & $\mathrm{C}$ & 1 \\
\hline 8 & 359 & $\mathrm{C}$ & 1 \\
\hline 9 & 737 & $\mathrm{C}$ & 1 \\
\hline 10 & 739 & $\mathrm{C}$ & 1 \\
\hline 11 & 772 & $\mathrm{C}$ & 1 \\
\hline 12 & 773 & $\mathrm{C}$ & 13 \\
\hline 13 & 788 & $\mathrm{C}$ & 3 \\
\hline 14 & 738 & $\mathrm{C}$ & 11 \\
\hline \multicolumn{3}{|c|}{ TOTAL } & 59 \\
\hline
\end{tabular}

Dengan demikian, maka dari 7 shared gare hanya ada 1 kategori tipe peesawat yang beroperasi dari total 59 pesawat kategori $\mathrm{C}$ dan rata-rata occupancy time sebesar 88 menit. Untuk ini didapatkan nilai mix berupa perbandingan jumlah 59 pesawat yang beroperasi, yaitu sebesar $100 \%$.

\begin{tabular}{|c|c|c|}
\hline $\begin{array}{c}\text { Aircraft } \\
\text { Class }\end{array}$ & Mix (\%) & $\begin{array}{c}\text { Average Occupancy Time } \\
\text { (min) }\end{array}$ \\
\hline $\mathrm{C}$ & 100 & 86 \\
\hline
\end{tabular}

Sehingga kapasitas gate untuk setiap gate adalah :

$$
\begin{aligned}
c & =\frac{1}{\text { Weighted Services Time }} \\
& =\frac{1}{(1 x 86)} \\
& =0,012 \text { pesawat } / \text { menit/gate }
\end{aligned}
$$

Jika G adalah total jumlah gate, kapasitas untuk seluruh gate adalah:

$$
\begin{aligned}
\mathrm{C}= & \mathrm{G} \times \mathrm{c}=7 \times 0,012 \\
& =0,08 \text { pesawat } / \text { menit } \\
& =4,88=4 \text { pesawat } / \mathrm{jam}
\end{aligned}
$$

Dengan demikian, jika diasumsikan gate digunakan pada jam operasional bandara yaitu mulai pukul 05.00 hingga pukul 21.00 yaitu selama 16 jam 7 buah shared gate ini dapat melayani hingga 64 pesawat.

\section{E. Kapasitas Penggunaan Gate yang Dipisah}

Berdasarkan disribusi penggunaan gate oleh airline dalam Tabel 6 maka diekatahui 7 gate yang telah disebutkan sebelumnya oleh satu maskapai tertentu,dengan komposisi untuk setiap kategori adalah sebagai berikut.

Tabel 6 .

Kompetisi Kategori Pesawat yang Beroperasi di Exclusive Gate Terminal 3 Ultimate

\begin{tabular}{|c|c|c|c|}
\hline No & Tipe & Kategori & Jumlah (buah) \\
\hline 1 & 738 & C & 67 \\
\hline \multicolumn{3}{|c|}{ TOTAI } \\
\hline
\end{tabular}

Dengan demikian, maka dari 7 exclusive gate yang ada hanya ada 1 kategori tipe pesawat yang beroperasi, yaitu kategori C dengan total 67 buah pesawat dan rata-rata occupancy time sebesar 1 jam 51 menit atau 71 menit. untuk itu didapatkan nilai mix berupa perbandingan jumlah 67 pesawat kategori $\mathrm{C}$ dari seluruh 67 pesawat yang beroperasi, yaitu sebesar $100 \%$

Tabel 7.

Average Occupancy Time Berdasarkna Kategori

\begin{tabular}{|c|c|c|c|}
\hline $\begin{array}{c}\text { Aircraft } \\
\text { Class }\end{array}$ & $\begin{array}{c}\text { Number of } \\
\text { Gates }\end{array}$ & $\begin{array}{c}\text { Mix } \\
(\%)\end{array}$ & $\begin{array}{c}\text { Avreager Occupancy } \\
\text { Time (min) }\end{array}$ \\
\hline $\mathrm{C}$ & 7 & 100 & 71 \\
\hline
\end{tabular}

Sehingga kapasitas gate untuk setiap gate adalah :

$$
\begin{aligned}
c & =\frac{1}{\text { Weighted Services Time }} \\
& =\frac{1}{71} x 60 \text { menit }
\end{aligned}
$$

$=0,845$ pesawat $/ \mathrm{jam}$

Jika $\mathrm{G}$ adalah total jumlah gate, kapasitas untuk seluruh gate adalah:

$$
\begin{aligned}
\mathrm{C}=\mathrm{G} \times \mathrm{c}=7 \times 0,845 \\
=5,91=5 \text { pesawat } / \mathrm{jam}
\end{aligned}
$$

Dengan demikian, jika diasumsikan gate digunakan pada jam operasional bandara yaitu mulai pukul 05.00 hingga pukul 21.00 yaitu selama 16 jam maka 7 buah exclusive gate ini dapat melayani hingga 80 pesawat.

Secara keseluruhan, kapasitas gate untuk mengakomodasi pergerakan pesawat adalah sebesar 4 pesawat per jam untuk semua shared gate dan 5 pesawat per jam untuk semua exclusive gate. Sehingga total pesawat yang dapat ditampung oleh semua gate adalah sebesar 9 pesawat per jam. 


\section{F. Jumlah Gate yang Dibutuhkan}

Dari hasil survey yang telah dilakukan, didapat data penerbangan turnaround flight yang selanjutnya dilkukan perhitungan untuk merencanakan penerbangan mana saja yang dapat dipindah, jadwal penerbangan dapat dilihat pada Tabel 8 .

Tabel 9

Jadwal Penerbangan yang Dapat Dipindahkan ke Gate

\begin{tabular}{|c|c|c|c|c|c|c|}
\hline No & NoI & light & Block & Block & Airlines & Available Gate \\
\hline & AII & Dep & & & & \\
\hline 1 & GA 0891 & GA, 0418 & $14: 00$ & $18: 58$ & GARAUDA INDONESIÁ, & $\cdot$ \\
\hline 2 & JL 0725 & JL 0726 & $16: 07$ & $22: 11$ & $\mathrm{JAQL}$ & \\
\hline 3 & SV 0820 & SV0815 & $16: 12$ & $18: 07$ & SAUDI & . \\
\hline 4 & $\mathrm{NH} 0855$ & $\mathrm{NH} 0856$ & $16: 35$ & $21: 29$ & ANA & $\cdot$ \\
\hline 5 & GA 0875 & GA 0874 & $16: 43$ & $23: 30$ & GARIUDA INDONESIA & 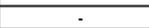 \\
\hline 6 & G8,0002 & GA 0568 & $5: 45$ & $14: 02$ & GARIUDA INDONESIA & . \\
\hline 7 & AK 0380 & AK 0381 & $8: 18$ & $9: 04$ & AIRASIA & $\cdot$ \\
\hline 8 & TR2274 & TR2275 & $9: 01$ & $9: 58$ & TIGERAIR SINGAPAPORE & . \\
\hline$\frac{9}{9}$ & JT 0287 & JT 0280 & $9: 14$ & $\frac{3: 100}{11: 44}$ & LION AIR & \\
\hline 10 & Q20203 & Q20264 & $11: 03$ & $12: 21$ & INDONESIA AIRASIA, & \\
\hline 11 & Q20263 & Q20256 & $11: 16$ & $13: 00$ & INDOONESIA, A.IRASIA, & - \\
\hline 12 & GA 0821 & GA 0110 & $13: 51$ & $15: 41$ & GARIUDA. INDONESIA & 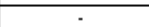 \\
\hline 13 & MF 8925 & MF 8926 & $14: 08$ & $16: 04$ & XIAMMEN AIRLLINES & \\
\hline 14 & AK 0 0384 & A.K 0385 & $14: 14$ & $15: 07$ & AIRASIA & \\
\hline 15 & QZ7553 & Q20266 & $14: 43$ & $15: 53$ & INDONESIA, AIRASIA, & . \\
\hline 16 & QZ7521 & QZ20200 & $14: 45$ & $15: 46$ & INDONESIA, AIRASIA & 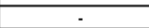 \\
\hline 17 & $\mathrm{MH} 0721$ & $\mathrm{MH} 0720$ & $14: 55$ & $19: 59$ & MÁLAYSIA AIRLIINES & \\
\hline 18 & 107156 & 106816 & $17: 31$ & $19: 00$ & BATIK AIR & 8 \\
\hline 19 & GA 0867 & GA 0822 & $17: 52$ & 20.53 & GARRUDA INDONESIA & \\
\hline 20 & XT 7515 & XT 7516 & $19: 15$ & $20: 37$ & INDONESIA AIRASIAXX & 14 \\
\hline 21 & TR 2272 & TR 2273 & $19: 16$ & $20: 30$ & TIGERAIR SINGÄAPORE & 15 \\
\hline 22 & QZ7531 & QZ7532 & $20: 05$ & $20: 53$ & INDONESIÁ AIRASSIA & 14 \\
\hline
\end{tabular}

Dapat dilihat dari Tabel 9 tersebut kemungkinan penerbangan yang dapat dipindahkan adalah 4 penerbangan Dari 4 penerbangan tersebut hanya 1 yang dapat dipindah. Dikarenakan 3 penerbangan lainnya hanya dapat dipindah ke exclusive gate dimana gate tersebut sudah di peruntukkan untuk penerbangan maskapai tertentu sehingga 3 penerbangan tersebut tidak dapat dipindahkan. Berdasarkan Tabel tersebut, dapat diketahui bahwa ada 3 penerbangan yang tetap tidak dapat terakomodir oleh gate yang ada. Sehingga dapat disimpulkan bahwa jika seluruh penerbangan yang beroperasi disumsikan menggunakan gate dengan garbarata, maka jumlah gate yang dibutuhkan melebihi jumlah gate yang ada saat ini yaitu 14 buah.

\section{G. Peramalan Pertumbuhan Pergerakan Pesawat Terhadap} Gate

Analisis perhitungan peramalan ini berdasarkan data pesawat di tahun 2011-2015 (sebagai data historis) yang diregresikan, yang dapat dilihat pada Tabel 10.. Dari persamaan ini didapat sebuah persamaan yang dimana peramalan jumlah penumpang di tahun 2016-2025 dapat diketahui. Hasil regresi dapat dilihat pada tabel 11 .

Tabel 10

Data Historis Total Pergerakan Pesawat Tahun 2011-2015

\begin{tabular}{|c|c|c|c|c|c|c|}
\hline \multirow{2}{*}{ No } & \multirow{2}{*}{ Bulan } & \multicolumn{5}{|c|}{ Total Pergerakan } \\
\hline & & 2011 & 2012 & 2013 & 2014 & 2015 \\
\hline 1 & Januari & 27441 & 30791 & 32885 & 34525 & 31270 \\
\hline 2 & Februari & 24411 & 28695 & 28324 & 28801 & 27432 \\
\hline 3 & Maret & 27676 & 31792 & 32164 & 31904 & 31419 \\
\hline 4 & April & 27246 & 30968 & 31659 & 30708 & 32049 \\
\hline 5 & Mei & 28466 & 32688 & 33527 & 32769 & 33957 \\
\hline 6 & Juni & 28636 & 32103 & 34330 & 33774 & 31418 \\
\hline 7 & Juli & 30268 & 31449 & 32299 & 30700 & 34920 \\
\hline 8 & Agustus & 27120 & 32322 & 36763 & 35221 & 34255 \\
\hline 9 & September & 29707 & 31792 & 34154 & 31863 & 30068 \\
\hline 10 & Oktober & 30297 & 32389 & 34427 & 33427 & 31980 \\
\hline 11 & Nopember & 28917 & 32084 & 33645 & 32252 & 32048 \\
\hline 12 & Desember & 30280 & 34004 & 35253 & 35040 & 35799 \\
\hline \multicolumn{2}{|c|}{ Total } & 340465 & 381077 & 399430 & 390984 & 386615 \\
\hline
\end{tabular}

Tabel 11

Hasil Peramalan Jumlah Pergerakan Total Pesawat di Gate Tahun 2016-2025

\begin{tabular}{|c|c|c|c|c|c|c|c|c|c|c|}
\hline Bulan & 2016 & 2017 & 2018 & 2019 & 2020 & 2021 & 2022 & 2023 & 2024 & 2025 \\
\hline Januari & 34800.2 & 35939.4 & 37078.6 & 38217.8 & 39357 & 40996.2 & 41635.4 & 42774.6 & 43913.8 & 45053 \\
\hline Febraari & 29376.8 & 29991.6 & 30606.4 & 31221.2 & 31836 & 32450.8 & 33065.6 & 33680.4 & 34295.2 & 34910 \\
\hline Maret & 33270.8 & 34030.6 & 34790.4 & 35550.2 & 36310 & 37069.8 & 37829.6 & 38589.4 & 39349.2 & 40109 \\
\hline April & 33329.6 & 34264.2 & 35198.8 & 36133.4 & 37068 & 38002.6 & 38937.2 & 39871.8 & 40806.4 & 41741 \\
\hline Mei & 35600.8 & 36707.1 & 37813.4 & 38919.7 & 40026 & 41132.3 & 42238.6 & 43344.9 & 44551.2 & 45557.5 \\
\hline Juni & 34223 & 34946.5 & 35670 & 36393.5 & 37117 & 37840.5 & 38564 & 39287.5 & 40011 & 40734.5 \\
\hline Juli & 34994 & 35349.5 & 36205 & 37060.5 & 37916 & 38771.5 & 39627 & 40482.5 & 41338 & 42293.5 \\
\hline Agustus & 38287.4 & 40004.3 & 41721.2 & 43438.1 & 45155 & 46871.9 & 48588.8 & 50305.71 & 52022.6 & 53739.5 \\
\hline September & 31754.8 & 31834.1 & 31913.4 & 31992.7] & 32072 & 32151.3. & 32230.6 & 32309.9 & 32389.2 & 32468.5 \\
\hline Ottober & 33825.4 & 34265.8 & 34706.2 & 351466.6 & 35587 & 36027.4 & 36467.8 & 36008.2 & 37348.6 & 37789 \\
\hline Nopember & 33718 & 34361 & 35004 & 35647 & 36290 & 36933 & 37576 & 38219 & 38862 & 39505 \\
\hline Desember & 37697,4 & 38904.8 & 40112.2 & 41319.6. & 42527 & 43734.4 & 49941.8 & 46199.22 & 47356.66 & 48564 \\
\hline Total & 410378.2 & 420598.9 & 430819.6 & 411040.3 & 451261 & 461481.7 & 4717024 & 4892321.1 & 492433.8 & 502364.5 \\
\hline
\end{tabular}

Setelah itu dilakukan dengan mencari Peak Month Ration, Peak Day Ratio, Peak Hour Ratio, lalu dilakukan perhitungan dengan mencari jumlah pesawat pada jam puncak di tahun rencana.

Dari hasil perhitungan peramalan yang didapat dari metode regresi linear yang dapat dilihat pada Tabel 12 menunjukkan bahwa hasil permalan ketersediaan gate pada tahun rencana sudah tidak mencukupi.

Tabel 12

Pertambahan Pergerakan Harian

\begin{tabular}{|c|c|c|}
\hline Tahun ke- & Tahun & Pergerakan \\
\hline 6 & 2016 & 334 \\
\hline 7 & 2017 & 338 \\
\hline 8 & 2018 & 342 \\
\hline 9 & 2019 & 346 \\
\hline 10 & 2020 & 350 \\
\hline 11 & 2021 & 354 \\
\hline 12 & 2022 & 358 \\
\hline 13 & 2023 & 362 \\
\hline 14 & 2024 & 366 \\
\hline 15 & 2025 & 370 \\
\hline
\end{tabular}

Tabel 13

Pertambahan Jumlah Penerbangan Jam Puncak

\begin{tabular}{|c|c|c|}
\hline Tahun ke- & Tahun & Penerbangan \\
\hline 6 & 2016 & 30 \\
\hline 7 & 2017 & 32 \\
\hline 8 & 2018 & 34 \\
\hline 9 & 2019 & 36 \\
\hline 10 & 2020 & 38 \\
\hline 11 & 2021 & 40 \\
\hline 12 & 2022 & 42 \\
\hline 13 & 2023 & 44 \\
\hline 14 & 2024 & 46 \\
\hline 15 & 2025 & 48 \\
\hline
\end{tabular}

Dari Tabel 12 dapat dilihat bahwa pertumbuhan pergerakan di tahun rencana sebanyak 370 pergerakan sudah melebihi kapasitas gate yang hanya dapat menampung sebanyak 336 pergerakan.

\section{KESIMPULAN DAN SARAN}

Kesimpulan dari hasil studi yang dilakukan antara lain sebagai berikut :

\section{A. Kesimpulan}

Secara umum pesawat yang beroperasi di Terminal 3 Ultimate Bandar Udara Internasional Soekarno-Hatta adalah pesawat dengan jenis narrow body dan wide body yaitu:

1. Narrow Body: dimana yang terbanyak adalah tipe B-738 sebanyak 78 buah dengan rata-rata ground handling 94 mnit.

2. Wide Body: dimana yang terbanyak adalah tipe A-333 yang berjumlah 5 buah dengan rata-rata ground handling 123 menit. 
3. Dengan rata-rata waktu aircraft turnaround sebesar 1 jam 38 menit atau 98 menit, maka hasil penggunaan gate kondisi eksisting adalah:

4. Dari 14 jumlah gate yang tersedia 7 diantaranya merupakan shared gate yang digunakan secara bersamasama oleh banyak maskapai dan 7 gate lainnya adalah exclusive gate yaitu gate 11, 12, 13, 14, 15, 16, 17 hanya digunakan oleh maskapai Garuda Indonesia penerbangan domestik.

5. Frekuensi penggunaan gate bervariasi dengan rata-rata selama 18 jam 2 menit dalam satu hari, atau rata-rata digunakan 18 kali dalam 1 hari. Gate 11 menjadi gate tersibuk dengan penggunaan sebanyak 18 kali dalam satu hari, dengan rata-rata penggunaan 1 jam 41 menit atau 101 menit, sedangkan gate yang jarang digunakan adalah gate $6,8,9,10$ dengan penggunaan sebanyak 8 kali dalam satu hari, dengan rata-rata penggunaan sebanyak 1 jam 23 menit atau 83 menit.

6. Pada bulan Agustus tahun 2016 dari 14 gate yang tersedia di Terminal 3 Ultimate dapat menampung 334 pergerakan dan batas maksimal yaitu 336 pergerakan di tahun 2016. Sedangkan menggunakan metode peramalan regresi linear pada bulan Agustus tahun 2025 terdapat 370 pergerakan. Melihat kondisi tersebut gate tidak dapat menampung secara maksimal.

7. Kinerja Terminal 3 Ultimate Dengan Gate yang tersedia

8. dari 168 turnaround flight yang beroperasi, didapatkan hanya 11 penerbangan yang on time dalam melakukan proses airport ground handling. Sisanya 157 penerbangan mengalami keterlambatan antara 1 menit hingga 257 menit dengan rata-rata 69 menit.

9. Keterlambatan yang terjadi antara lain disebabkan oleh beberapa hal seperti menunggu izin dari tower untuk terbang dikarenakan adanya traffic, adanya penumpang yang telah check in terlambat untuk masuk ke dalam pesawat, adanya penggunaan kursi roda atau pelayanan khusus lainnya, dan kesigapan petugas airport ground handling dalam melakukan pelayanan di apron.

10. Dari hasil perhitungan masing-masing untuk shared gate dan exclusive gate, didapatkan kapasitas tiap gate untuk 7 buah shared gate yang ada sebesar 4 pesawat/jam, dan kapasitas tiap gate untuk 7 buah exclusive gate yang ada sebesar 5 pesawat/jam.

\section{B. Saran}

Untuk mendapatkan kenyamanan para pengunjung maka harus ditunjang dengan ketersediaan gate yang optimal, jika perlu PT. Angkasa Pura II melakukan penambahan gate untuk mengakomodir kebutuhan operasional penerbangan di tahun rencana.

Perlu dilakukan pengawasan yang ketat oleh PT. Angkasa Pura II untuk seluruh maskapai dan airport ground handling agar pelayanan dapat lebih efektif sehingga dapat mengurangi keterlambatan

Dari hasil analisis data penerbangan Terminal 2 yang tidak dapat dipindahkan ke Terminal 3 Ultimate tetap pada semula yaitu di Terminal 2. Dikarenakan gate yang sudah tidak memadai dan adanya persamaan jam penerbangan.

\section{DAFTAR PUSTAKA}

[1] Keputusan Menteri Perhubungan No. 11 tahun 2010 Tentang Tatanan Bandara Internasional Soekarno-Hatta.

[2] Data Statistik. Kantor Pusat Statistik Angkasa Pura II. Tangerang, 2016.

[3] Horonjeff, R. F. Mckelvey, X.. Sproule, W. J and Young, S. B. 2010. Planning and Design of Airports, Fifth Edition. The McGraw-hill Companies, Inc.

[4] Aircraft Manual For Airport Design. 2013 http://www.boeing.com/assets/pdf/commercial/airports/acaps/737.pdf.

[5] Kreditgogo.com., 20165 Fakta Tentang Terminal 3 Ultimate SoekarnoHatta, <https://kreditgogo.com/ artikel/Informasi-Umum/5-FaktaTentang-Terminal-3 -Ultimate-Soekarno-Hatta.html>

[6] Rahayu, H., Ahyudanari, E. (2016). "Evaluasi Kinerja Gate Assignment pada Terminal 1 Keberangkatan Domestik Bandar Udara Internasional Juanda Surabaya”. Jurnal Teknik Vol.5, No 1. Fakultas Teknik Sipil dan Perencanaan. Institut Teknologi Sepuluh Nopember, Surabaya.
[7] Sari, N. 2005. Analisa Penentuan Jumlah Gate pada Terminal Keberangkatan Domestik di Bandara Internasional Juanda Surabaya (Terminal Lama). Tugas akhir. Fakultas Teknik Sipil dan Perencanaan. Institut Teknologi Sepuluh Nopember, Surabaya.

[8] Ashford, N. J., Mumayiz, S., dan Wright, P. H. 2011. Airport Engineering : Planning, Design, and Development of 21st Century Airports, Fourth Edition. Hoboken : John Wiley \& Sons, Inc.

[9] Noviar, P. A. 2017. Evaluasi Ketersediaan Gate di Terminal 3 Ultimate Bandar Udara Internasional Soekarno-Hatta. Tugas Akhir. Fakultas Teknik Sipil dan Perencanaan. Institut Teknologi Sepuluh Nopember, Surabaya. 